\title{
Barış Gazeteciliği Bağlamında Türkiye Medyasında Ezidiler ve Türkmenler ${ }^{*}$
}

\author{
Ceren SARAN \\ Ceren ACUN \\ Çağlayan Koşal AKPINARLI \\ Gökhan ARIKAN \\ Ayşenur ÖLMEZSES ŞENTÜRK \\ Sergül TAŞDEMIR
}

doktora öğrencileri, galatasaray üniversitesi medya ve iletişim çalışmaları ceren.saran / cerenacun04 / caglayankosal@gmail.com garikan@hacettepe.edu.tr

a.olmezses / sergultasdemir@gmail.com

\section{Abstract \\ The representation of Yazidis and Turkmens in terms of Peace Journalism on Turkish media}

This study aims at investigating the representation of Yazidi and Turkmen people on Turkey's media following the occupation of Şengal (Sincar) by ISIS. While the research is based on the principles of peace journalism, a critical approach has also been adopted. Newspapers Evrensel, Birgün, Cumhuriyet, Hürriyet, Sabah and Yeniçağ have been selected as sample regarding their political and economic positions together with their publishing principles, and they have been examined based on the proposed principles of peace journalism. The principles of the critical discourse analysis applied to the newspapers published between the dates 4 - 31 August 2014, the findings have been evaluated and the results have been discussed in the context of peace journalism principles. At the end of the research, it is seen that the newspapers that are subjected to critical discourse analysis are far from the peace journalism principles of Lynch and McGoldrick who suggest the media can take a positive role for encouraging and promoting peace. Also, Yazidis and Turkmens are represented as "we/other" depending on the ideological position of the newspaper, rather than the "victim" of the war.

keywords: peace journalism, critical discourse analysis, representation, Yazidis, Turkmens

* Bu çalışma, Galatasaray Üniversitesi Medya ve İletişim Çalışmaları Doktora Programında yer alan ve Prof. Dr. Yasemin İnceoğlu tarafından yürütülen Uluslararası Illetişim dersi kapsamında hazırlanmıştır. 


\section{Résumé}

\section{La représentation des Turkmènes et des Yézidis dans le contexte du journalisme de paix dans les médias de la Turquie}

Cette étude vise à étudier la représentation des Yézidis et des Turkmènes dans les médias de la Turquie suite à l'occupation du Şengal (Sincar) par Daesh. Bien que la recherche repose sur les principes du journalisme de paix, une approche critique a également été adoptée. Les journaux Evrensel, Birgün, Cumhuriyet, Hürriyet, Sabah et Yeniçağ ont été sélectionnés au regard de leurs positions politiques et économiques en même temps de leurs principes éditoriaux et ont été examinés sur la base des principes proposés du journalisme de paix. Les résultats de l'analyse critique du discours appliquée aux journaux publiés entre le 4 et le 31 août 2014 ont été évalués et les résultats ont été discutés dans le contexte des principes du journalisme de paix. À la fin de la recherche, on constate que les journaux analysés sont loin des principes du journalisme de paix de Lynch et McGoldrick qui suggèrent que les médias peuvent jouer un rôle positif pour encourager et promouvoir la paix. Pareillement, Yazidis et Turkmènes sont représentés comme "nous / autres" d'une manière idéologique, plutôt que "victime» dans les nouvelles.

mots-clés: journalisme de paix, analyse de discours critique, représentation, Yézidis, Turkmènes

\section{Öz}

Bu çalışma, IŞiD'in 2014 Şengal (Sincar) işgalini takiben Ezidi ve Türkmenlerin Türkiye medyasında yer alan temsillerini barış gazeteciliği yaklaşımı bağlamında sorgulamaya açmayı amaçlamaktadır. Barış gazeteciliği ilkeleri araştırmanın temelini oluşturmakla birlikte, bu yaklaşıma eleştirel bir bakış açısı getirebilmek de hedeflenmiştir. Araştırmanın örneklemini oluştururken siyasi ve ekonomik konumlanmaları ile yayın kimlikleri göz önünde bulundurularak seçilen Evrensel, Birgün, Cumhuriyet, Hürriyet, Sabah ve Yeniçağ gazetelerinin konuya ilişkin ilk sayfa haberleri, barış gazeteciliğinin önerdiği ilkeler kapsamında incelenmiştir. 4-31 Ağustos 2014 tarihleri arasında gazetelerin eleştirel söylem analizi yöntemi ile incelenmesi sonucu elde edilen bulgular, barış gazeteciliği yaklaşımı bağlamında değerlendirilmiştir. Araştırmanın sonucunda incelenen gazetelerin, Lynch ve McGoldrick'in, medyanın barışı özendirme ve destekleme konusunda pozitif bir rol oynayabileceği yönündeki barış gazeteciliği tezinden uzak olduğu; Ezidiler ve Türkmenlerin, "mağdur" yerine ideolojik bir tutumla "bizl öteki" şeklinde temsil edildiği görülmüştür.

anahtar kelimeler: barış gazeteciliği, eleştirel söylem analizi, temsil, Ezidiler, Türkmenler 


\section{Giriş}

Suriye'de beş yıldır bir savaş sürüyor. Arap Baharı ile 2011 yılında başlayan isyanlar silahlı çatışmalara dönüşmüş ve 2013 yılında Birleşmiş Milletler İnsan Hakları Konseyi raporuna "bariz derecede mezhepsel" kategorisiyle girmiş durumda. ${ }^{1}$ Bugün ise birden çok devletin silahlı birlikleriyle dâhil oldukları bir savaş devam etmekte. Bu savaş Türkiye Cumhuriyeti Hükümeti'nin uluslararası politikaları sonucunda beş yıl içinde yükselerek Türkiye'nin ana gündem maddelerinden biri haline gelmiştir. Türkiye'nin iç meselesi olarak tanınan alanlar uluslararası boyuta ulaşmış ve Türkiye için uluslararası olan çatışmalar ise Irak ve Şam İslam Devleti'nin (IŞiD) saldırıları sonucunda ülkenin iç siyasetinde önemli bir konuma gelmiştir. Bunun yanında ciddi bir nüfus, temel insan haklarından mahrum kalmıştır. Savaş bu boyutuyla bir mülteci krizini de beraberinde getirmiştir. Türkiye ise yine bu krizin merkez konumunda yer alan ülkelerden biri olmuştur.

Araştırmamız, Suriye iç̧ Savaşı kapsamında farklı güçlerin saldırılarına maruz kalmış iki etnik grup olan Ezidilerin ve Türkmenlerin, Türkiye'de siyasi iktidar yanında ve karşısında konumlanan farklı siyasi çevreler tarafından sahiplenildiğini, bu nedenle haberlerin içerik yönünden farklılk göstereceği ön kabulünden hareket etmektedir. Incelenecek gazetelerin seçiminde; Türkiye'deki medya düzenindeki siyasi ve ekonomik konumlanmaları, yayın kimlikleri ile yayın politikaları göz önünde bulundurulmuştur. Gazetelerin birinci sayfalarında yer alan logo ve sloganları ise, çıkış noktamızı güçlendirir niteliktedir. Evrensel gazetesi "Emek Evrensel'dir", Birgün "Halkın gazetesi" sloganıyla yayınlanırken; Hürriyet, logosunun yanında Atatürk ikonu ve Türk bayrağı ile "Türkiye Türklerindir" sloganıyla yayınlanmaktadır. Sabah gazetesinin logosunda Türkiye haritası bulunurken, Yeniçağ gazetesi de logosunun yanında Türk bayrağı ve Atatürk resmi ile "Bu memleket tarihte Türk'tü, bugün de Türk'tür ve ebediyen de Türk olarak yaşayacaktır. Türkiye Türklerindir" satırlarıyla yayınlanmaktadır. Cumhuriyet gazetesinin ise herhangi bir sloganı bulunmamaktadır.

Araştırma kapsamında yapılan eleştirel söylem analizi sonucu elde edilecek bulgular; barış gazeteciliğinin dikkat çektiği, haber üretiminde kalıp yargılar kullanma ve ötekileştirme gibi haberciliğin sorunlu yanlarının nasıl yer aldığı dikkate alınarak tartışılacaktır. Çalışmamız, incelenen haberlerin, medyanın içinde bulunduğu ekonomi politik koşullardan bağımsız üretilmediği ön kabulüyle gerçekleştirilmiş ve gazetelerin sermaye yapıları ile sahiplik ilişkileri, araştırma kapsamı dışında bırakıımıştır. Sorunsalımız; Ezidiler ve Türkmenlerin, siyasi kamplaşmaya teslim olmuş Türkiye medyasındaki temsilinin, barış gazeteciliği bağlamında neye karşılık geldiğidir. Araştırma sorularımız ise şöyledir: Türkiye medyasında Ezidiler ve Türkmenler nasıl temsil edilmiştir? Medyada yer alan

1 Raporun tamamı için bkz.: http://www.ohchr.org/Documents/HRBodies/HRCouncil/ColSyria/A. HRC.22.59_en.pdf, Erişim: 03.01.2016. 
haberler barışı özendirme ve desteklemede pozitif bir rol oynamış mıdır? Barış gazeteciliği bu kapsamda uygulanabilir ve çözüm odaklı yöntemler önermekte midir?

Varsayımlarımız; aşağıda yer almaktadır:

- Türkiye siyasi iktidarının ve bu iktidara alternatif yapıların, Ezidi ve Türkmenlerin maruz kaldığı saldırılarla ilgili tutumları ve incelenecek gazetelerin siyasi iktidar karşısında konumlanışı, konuyla ilgili haberlerin üretilmesi üzerinde etkili olmuştur. Bu haberlerin sunumunun barış gazeteciliği ile tutarlı ya da tutarsız oluşu, çalışmanın sonunda tartışılacaktır.

- Ezidiler ile Türkmenlerin nasıl temsil edildiği, gazetelerin yayın kimliği ve yayın politikalarına göre farklılaşmaktadır.

- Ezidiler ile Türkmenler üzerine yapılmış haberler, barış gazeteciliğinin savunduğu ilke ve değerleri yerine getirmekten çok, partizan bir söylemle yapılmaktadır.

- Siyasal alanda farkı kutuplarda yer alan yapılar ve bu grupları temsil eden medya kuruluşları, benzer durumda olan iki farklı etnik gruba farklı haber değerleri biçerek "mağdur" durumdaki bu iki toplumu stratejik amaçlı kullanma eğilimindedirler. Bu eğilim "biz" ve "öteki" gibi ilkel ikiliklerden daha karmaşık bir düzlemde barış gazeteciliğinin imkânlarını ortadan kaldırmaktadır.

Araştırma için belirlenen zaman aralığı, IŞiD'in 3 Ağustos 2014'te, Kuzey Irak'taki Şengal'i (Sincar) işgalini takip eden 4-31 Ağustos 2014 tarihleridir. 2014 yılının Haziran ayında IŞiD, Kuzey Irak'ta yaygın bir işgal operasyonuna başlamış, Haziran ayında Telafer gibi Türkmen nüfusun yoğun olarak yaşadığı kentleri ele geçirmiştir. Bölgede yaşayan Türkmen nüfus göçe zorlanmış, Türkiye'ye sığınmışlardır. Ağustos ayında ise IŞiD'in, Irak Kürdistan Bölgesel Yönetimi'ne bağlı Peşmerge güçlerinin kontrolünde olan Şengal'i işgal etmesiyle bölgede yaşayan Ezidiler IşiD'den kaçarak Şengal Dağı'na sığınmıştır. Birleşmiş Milletler Insan Hakları Yüksek Komiserliği tarafından hazırlanan rapor (2014) uyarınca, 200.000 sivil, güvenlik arayışı ile kasabayı terk ederek Şengal Dağı'na sığınmışlardır. Aralarında binlerce kadın, çocuk, engelli ve yaşıı insanların bulunduğu yerlerinden edilmiş sivillerin uzun mesafeyi yürüyerek geçmek durumunda kalmaları, insani intiyaçları olan su, kalacak yer ve tıbbi yardıma erişimlerinin olmaması, insani bir krize yol açmıştır. ${ }^{2}$

2 Birleşmiş Milletler İnsan Hakları Yüksek Komiserliği raporunun tamamı için bkz: http://www.ohchr. org/Documents/Countries/IQ/UNAMI_OHCHR_POC_Report_FINAL_6July_10September2014. pdf, Erişim: 03.01.2016. 


\section{Kavramsal Çerçeve: Barış Gazeteciliği}

Araştırmamızın kavramsal çerçevesi, basının toplumsal alan içinde eyleyen bir oyuncu olduğunu, gazetelerin ve gazetecinin de bu eylemde aktif bir pozisyona oturduğunu vurgulayan barış gazeteciliğine dayanır. Johan Galtung'un 1960'lardan itibaren önderlik ettiği barış ve çatışma çalışmalarının teorik birikimi üzerine kurulan barış gazeteciliği, özellikle Jake Lynch, Annabel McGoldrick gibi akademisyenlerin çalışmalarıyla geliştirilmiştir. Kuram en genel haliyle basının basmakalıp içerik üretim yöntemlerini eleştirerek, tarafgirlik ile barışın özendirilmesi gerektiğini öne sürmektedir. Türkiye medyası ise, hali hazırda iktidar merkezli keskin bir kamplaşma içindedir. Çalışmamı bu noktada barış gazeteciliğinin temel ilke ve önermelerine değinerek böylesi bir yapı içindeki Türkiye basınını analiz etmek istemektedir.

Lynch ve McGoldrick'in (2005) ileri sürdüğü barış gazeteciliği kavramının temelinde yatan önerme, medyanın, barışı özendirme ve destekleme konusunda oynayabileceği pozitif bir rolün olduğudur. Dolayısıyla barış gazeteciliği sadece barıştan yana bir gazeteciliği ifade etmediği gibi, çatışmaları şiddet yoluyla besleyen mevcut anlayışın aksine, çözüm odaklı, yapıcı ("yaratıcı") bir gazeteciliği ifade eder. Etiketleme, düşmanlaştırma, canileştirme, basmakalıp yargılar kullanma ve suçlama gibi haberciliğin sorunlu "basmakalıp" alanlarına çözümler üretmiş yeni meslek kodlarının geliştirilmesi gerektiği iddia edilmektedir. Bu kodlar sayesinde de barış gazeteciliği özendirilmiş olacaktır.

Mesleki etik kodlara göre, herhangi bir çatışma yalnız iki taraftan ibaret değildir ve içinde farklı amaçlara sahip pek çok oyuncu barındırır. Bu taraflar içinde verili ve sabit "iyi" ve "kötü" oyuncular yoktur ve bu oyuncular bir anda çatışma içerisinde belirmemiş, belli bir tarihsellik içinde oluşmuşlardır. Gazetecinin dikkate alması gereken hem bu tarihsellik, hem de çatışmanın geleceğe uzanan etkileridir. Bu sürecin ifşası için, gazetecinin "yetkili mercilere başvurması yeterli kaynak değildir; gazeteci sessizlerin sesine kulak vermeli ve çatışmayı baki görmektense haberini ortak çözüm zemini üzerine kurmalıdır. Bu zemin, şiddetin temsilinin dışına taşınmasını gerektirir. Bu dış alanda basit bir "öteki" ve "biz" karşıtlığı yoktur, aksine tüm tarafların ortak mağduriyetleri ön plandadır. Buna göre gazeteci haberini kurarken etken ve edilgen ikiliğini buyuran basmakalıp yargıların dışında durmalı ve çatışan iki tarafın da yalanlarını ifşa edip "doğru"larını öne sürmelidir. Tüm bunların mümkün olması ancak askeri/rekabetçi dilin dışında durmakla mümkündür. Özetle barış gazeteciliğinin etik kodu "onlar kazanırsa biz kaybederiz" yerine, "gemi batarsa hepimiz boğuluruz" önermesi etrafında kurulur.

Lynch ve McGoldrick, barış gazeteciliğini şöyle tanımlamaktadır: "Barış gazeteciliği, editör ve muhabirlerin, topluma; çatışma karşısında şiddet içermeyen karşııkların önemsenmesi ve değerlendirilmesi fırsatı yarattığı noktada - hangi haberleri nasıl aktaracağı konusunda - seçimler yaptığı andır." (2005, s. 5). Lynch 
ve McGoldrick'e göre, barış gazeteciliği düşünümsellik ya da eleştirel farkındalık sağlamaktadır. Bu önermeye göre, çatışmayı takip ederken, Çatışma Analizi ve Barış Araştırmaları alanlarında yapılan çalışmaların ışığında hareket etmek gerekmektedir. Buna göre temel bulgular şöyle belirtilmektedir:

- Şiddet kendiliğinden oluşmaz

- Şiddet içermeyen karşılıklar her zaman mümkündür

- $\quad$ ikiden çok taraf vardır

- Her bir tarafın kendi çıkarı vardır

Çatışma ve medyaya daha kapsayıcı bir bakış getirmeyi hedefleyen barış gazeteciliği kavramının "barış savunması" olarak algılamanın yanlış olacağını belirten Lynch ve McGoldrick, önermenin daha çok ulusal ve uluslararası tartışmalarda "barışa şans verme", yani şiddet içermeyen karşılıkların da mümkün olabileceğini aktarma görevi olarak görmenin daha iyi olacağını savunmaktadır (2005, s. xxi). Genel-geçer gazetecilik kapsamında yapılan habercilik ile barış gazeteciliğinin öngördügü habercilik yaklaşımını karşılaştıran Lynch ve Goldrick, iki anlayış arasındaki farkları bir tablo haline getirmiştir (aktaran Alankuş, 2016, s. 15):

Tablo 1. Lynch ve Goldrick'e göre (2005) "Genel-Geçer Gazetecilikte ve Barış gazeteciliğinde gazetecilik/habercilik karşılaştırmaları" (Alankuş, 2016, s. 25)

\begin{tabular}{|l|l|}
\hline Eski rol & Yeni rol \\
\hline Gözetleyici & Kolaylaştıııı \\
\hline Yorumlayıcı & İetişim sağlayıcı \\
\hline Haberleştirdiklerinden bağımsız & Bağımsız ancak karşıııkı bağımlııı içinde \\
\hline Gözlemleyici & Aynı gemide \\
\hline Öyküleştirme & Öyküleştirme \\
\hline Tartışan & Diyalog kuran \\
\hline Farkıııkları vurgulayan & $\begin{array}{l}\text { Farkıııkları gözardı etmeden ortak zemini } \\
\text { vurgulayan }\end{array}$ \\
\hline Gazeteciliğe yaklaşım & Gazeteciliğe yaklaşım \\
\hline Basitleştirici & Karmaşıklığı sergileyen \\
\hline Şiddet karşısında reaktif & $\begin{array}{l}\text { Çatışmayı anlamaya, nedenlerini ortaya çıkarmaya } \\
\text { çalışan }\end{array}$ \\
\hline Olay-temelli haberleştirme & Süreç temelli haberleştirme \\
\hline "Tarafsızım" & "Hakkaniyetliyim” (fair) \\
\hline $\begin{array}{l}\text { Dengeli haber yapıyorum: Her iki tarafa da } \\
\text { eşit ağırlık veriyorum }\end{array}$ & $\begin{array}{l}\text { Dengeyi, bütün tarafların öykülerini ve algılarını } \\
\text { vererek sağlıyorum }\end{array}$ \\
\hline
\end{tabular}




\begin{tabular}{|l|l|}
\hline İzleyici/Okura yaklaşım & İzleyici/Okura yaklaşım \\
\hline $\begin{array}{l}\text { Şiddetin sonuçlarını ölü, yaralı sayısını } \\
\text { bilmekten ibaret gören bir izleyici/okur } \\
\text { varsayan }\end{array}$ & $\begin{array}{l}\text { İzleyici/okuru sorun çözücü olarak tartışmanın içine } \\
\text { alan, katan }\end{array}$ \\
\hline $\begin{array}{l}\text { Gündemi haber merkezinin tercihlerine göre } \\
\text { belirleyen/"biz en iyisini biliriz" }\end{array}$ & $\begin{array}{l}\text { Sokaktaki insan gündemini gözeten/onun görüşü- } \\
\text { nü alan }\end{array}$ \\
\hline İleyicinin/okurun bilmeye hakkı var & $\begin{array}{l}\text { İleyici/okurun demokratik/siyasal süreçlere } \\
\text { katılmaya hakkı var }\end{array}$ \\
\hline "Ben ne yapıyorsam gazetecilik odur" & $\begin{array}{l}\text { Yaptığını gerekçelendiren, esnek ve değerleri } \\
\text { gözeten }\end{array}$ \\
\hline
\end{tabular}

Bu yaklaşımlardan hareketle Alankuş (2016), Türkiye'de barış gazeteciliğinin uygulanması açısından elverişli dönemlerden geçilmesine rağmen, bu uygulamanın önündeki engellerin, genel-geçer gazeteciliğin ilke ve kodlarına içkin yapısal sorunlardan öte, çok katmanlı olduğuna dikkat çekmektedir:

Çünkü geleneksel anlamdaki 'iyi' gazeteciliğin zaten hiç yapıl(a)mamış olduğu, başka ifadeyle medyanın askeri, siyasal ve ekonomik güç merkezlerinden hiçbir zaman bağımsız olmadığı; tarihinde savaş ve çatışma kışkırtıcıı̆ğı yaptığına dair bolca örnek bulunan; sadece güç merkezlerini yeterince desteklemediğinde kendisinden hesap vermesi beklenirken, okur/izleyicisine herhangi bir hesap verme sorumluluğu hissetmeyen bir haber medyası ile karşı karşıyayız. (Çoban'dan aktaran Alankuş, 2016, s. 25).

Alankuş'a göre Türkiye'de barış gazeteciliğinin uygulamaya geçirilememiş olmasının nedeni; büyük sermaye medyası ile yerel medyanın, siyasi ve askeri güç merkezlerinin politikalarından bağımsız davranma geleneğinin olmaması ile 2000'lerin ortalarından itibaren siyasal iktidarın müdahaleleriyle biçimlenen medya sahiplik yapısındaki değişme ile ortaya çıkan, gönüllü veya korkuyla dayalı bağımlıııtır (2016, s. 29). Alankuş'un bu saptaması varsayımlarımızla doğru orantılı olup; çalışma, incelenen haberlerin, medyanın içinde bulunduğu ekonomi politik koşullardan bağımsız üretilmediği önkabulüyle gerçekleştirilmiştir.

\section{Araştırma Kapsamı ve Metodoloji}

Van Dijk'a göre haber, bir tür değil bir söylemdir; haberin söylemi ise toplumda var olan egemen söylemlerin bir ürünüdür (aktaran İnal, 1996, s. 97). Söylem, ideolojilerin yeniden üretiminde ve günlük ifadelerde vazgeçilmez bir rol oynamaktadır (Van Dijk, 2015, s. 15). Eleştirel söylem analizi "sosyal ve politik bir tutum" olması sebebiyle bir araştırma yönteminden öte bir disiplin olarak değerlendirilmektedir (aktaran İnceoğlu ve Akgün Çomak, 2009, s. 30).

Van Dijk'in çözümlemesinin gücünün, haberi bir tür değil söylem olarak ele almasından geldiğini savunan Durna ve Kubilay'a göre; habere ilişkin bu yaklaşım, haberin hem metinsel düzeyde, hem de onun çözümleme çerçevesini farklı kılan 
üretim, alımlama/yorumlama düzeylerinde çözümlenmesini sağlamaktadır (2010, s. 67). Buna göre, üç düzeyden oluşan bir çözümleme çerçevesi sunan Van Dijk; haber yapımının kurumsal pratikleri ile medya söyleminin yapısıyla doğrudan ilişkili olan ekonomik ve toplumsal pratikler (üretim süreçleri) ile kavrama, hatıllama ve yeniden üretimi (alımlama süreçleri) içeren bir analiz öngörmektedir (aktaran Durna ve Kubilay, 2010, s. 67-68).

Van Dijk'a göre eleştirel söylem analizi, makro ve mikro yapıları ayrı ayrı ele almalıdır. Makro yapının en tepesinde başlık vardır, ardından gelen haber girişi (lead), makro yapının tepesinde yer alır. Ardından daha altta yer alan makro önermeler, daha az öne çıkan şematik kategoriler gelir; tarih ve yorumlar gibi (Van Dijk, 1988a, s. 15). Mikro yapılar ise sesler, kelimeler, cümle yapıları ve bunların anlamlarından oluşmaktadır (Van Dijk, 1988b, s. 26). Van Dijk'e göre, mikro yapılar yerel anlamların, kelimelerin, cümleler ve cümle bağlantılarının analizinden başlamalıdır (1988a, s. 99). Makro yapıları tematik ve şematik analiz olmak üzere iki aşamada inceleyen Van Dijk, tematik yapıların metnin en önemli bilgilerini içerdiğini; politik ve tarihi bağlam ile arka plan gibi alt temaların da ortaya çıkmasını sağladığını belirtir (1988a, s. 72-73).

Van Dijk'a göre, tematik çözümlemede, en önemli unsur, hiyerarşik yapılardır. Bunlar ise; üst başlık, başlık, alt başlık, spot, haber girişleri, haberler, hikâyeler, olaylar şeklinde devam eder. Şematik çözümlemede ise durumsallığa ve yorumlara yer verilirken, hikâye veya olay örgüsü ile yapısı değerlendirilir. Durumsallığa ilişkin bilgi verilir; haberin verildiği ve gerçekleştiği tarih, haberin işleniş biçimi, bilgisellik ve art alan bilgisi ele alınır. Mikro yapı çözümlemelerinde ise haberin cümle yapıları üzerinde duran Van Dijk, metni cümle yapılarının yanı sıra, kelime ve kelime öbeklerinin seçimi ve retorik açısından inceler (aktaran Giritli İnceoğlu ve Akgün Çomak, 2009, s. 31-32).

Araştırma kapsamında seçilen Birgün, Sabah, Hürriyet, Cumhuriyet, Evrensel, Yeniçağ gazetelerinin incelenmesinde, Van Dijk'in eleştirel söylem analizi yaklaşımı benimsenmiş ve bulgular, barış gazeteciliği yaklaşımı bağlamında incelenmiştir. Saldırıların başladığı 4 Ağustos 2014 tarihinden, devam ettiği 31 Ağustos 2014 tarihine kadar konuya dair gazetelerin ilk sayfasında yer bulmuş tüm haberler taranmıştır.

Örneklemin oluşturulmasındaki temel dayanak, incelenen konunun taraflarının ve aktörlerin temsiliyetlerinin ortaya konulmasıdır. Bu yüzden konuya yaklaşımda farklı noktalarda duran ve Türkiye medyasında farklı yaklaşımları temsil iddiasında bulunan gazeteler seçilmiştir. Örneklemi oluşturan gazeteler; Türkiye medyasının çeşitli sosyo-ekonomik ve siyasal kutuplarını temsil eder niteliktedir. İdeolojik ve politik temsiliyetlerinin yanı sıra bu gazetelerin yayın kimliği ve yayın politikalarının da haberlere yansıyacağı varsayılmışıır. 
Örneklem; sol, merkez ve sağ ideoloji içerisinde sayılabilecek gazetelerden oluşmaktadır. Sosyalist solu temsilen, Kasım 2016 itibarıyla haftalık 6.259 tirajlı Evrensel ve 18.242 tirajlı Birgün gazeteleri seçilmiştir. Insan hakları ve demokrasiyi ön plana alması beklenen bu gazetelerde, Ezidilere haber seçimi ve dağılımında daha çok yer verilmesi ve konunun toplumsal ve siyasi bağlamı içinde işlenmesi beklenmektedir. Tiraj verisi 73.190 olan Cumhuriyet gazetesi, merkez solu; örneklemin merkezinde bulunan, 331.252 tirajı olan Hürriyet ise, ana akım medyayı temsil etmektedir. Merkez sağda yer alan 303.512 tirajı Sabah gazetesi, hükümete yakınlığıyla da bilinmekte ve haberlerinde resmi politikalara paralellik göstermesi beklenmektedir. Milliyetçi çizgide yayın yapan 51.226 tirajı Yeniçağ ise örneklemin en sağ gazetesidir ve Türkmenler ile ilgili haberlere ağırlık verilmesi beklenmektedir. ${ }^{3}$

Gerçekleştirilen incelemeyle araştırmanın nesnesi olan haberlerin barış gazeteciliği açısından irdelenmesi hedeflenmektedir. Araştırmamızın konusunu oluşturan Ezidiler ve Türkmenler vakaları ise görünür halde çok sayıda aktörün içinde yer aldığı bir alanda cereyan etmiştir. Her medyanın kendi "biz" ve "onlar" ını kurduğu bir sahada (başka bir ifadeyle "ikilikler enflasyonunda"), ikilikleri aşıp tüm aktörlerin sesini duyurmasını sağlamanın olanakları incelenmelidir. Söylem analizinin araştırmanın kapsamı içinde barış gazeteciliğinin sunduğu olanaklardan çok, barış gazeteciliğinin mümkün olup olmadığını sorgulaması beklenmektedir.

\section{4-31 Ağustos 2014 Tarih Aralığında Gazetelerde Ezidi ve Türkmenlerin Temsili}

Araştırma bulguları, Van Dijk'in eleştirel söylem analizi için geliştirdiği makro ve mikro yapılar ayrıştırması uyarınca iki başlık altında kategorize edilerek değerlendirilmiştir. Bu iki başlıkta değerlendirilen bulgular, Lynch ve McGoldrick'in barış gazeteciliği yaklaşımı bağlamında incelenmiştir.

\section{Makro yapılar}

4-31 Ağustos 2014 tarihleri arasında Evrensel, Birgün, Cumhuriyet, Hürriyet, Sabah ve Yeniçağ gazetelerinin birinci sayfalarından referans verilen haberlerin incelenmesi sonucu elde edilen bulgular aşağıda yer almaktadır. Araştırma kapsamında incelenen toplam haber sayısı 74 olup, haberlerin gazetelere göre dağılımı şöyledir: Evrensel 21, Birgün 5, Cumhuriyet 12, Hürriyet 9, Sabah 5, Yeniçağ 21. Toplamda incelenen 73 haberin yalnızca 8'i görsel öge kullanılmadan yayınlanmıştır.

Van Dijk başlığı, makro yapının en tepesinde konumlandırmakta, başlığın en üstte yer alan makro önerme olduğunu vurgulamaktadır (Van Dijk, 1988a, s. 15).

3 Tiraj verileri, 31.10.2016-06.11.2016 haftasının ortalama satış rakamlarından oluşmaktadır. YAYSAT web sitesinde Birgün, Sabah ve Yeniçağ'a ait veriler bulunmadığı için kaynak olarak "Medyatava" adlı websitesi esas alınmıştır. Erişim: 14.11.2016. http://medyatava.com/tiraj 
Bu doğrultuda; temalar ve konular, başlık ve giriş paragraflarında verilirken, başlık ve giriş paragrafı, gazetecinin olayı nasıl gördüğünü ve tanımladığını göstermekte, ayrıca okuyuculara, haberin makro yapılarını hatırlatmaktadır (Van Dijk'ten aktaran Durna ve Kubilay, 2010, s. 69).

\section{Haber dağılımı ve haber kaynakları}

Tablo 2. Konularına göre haberler

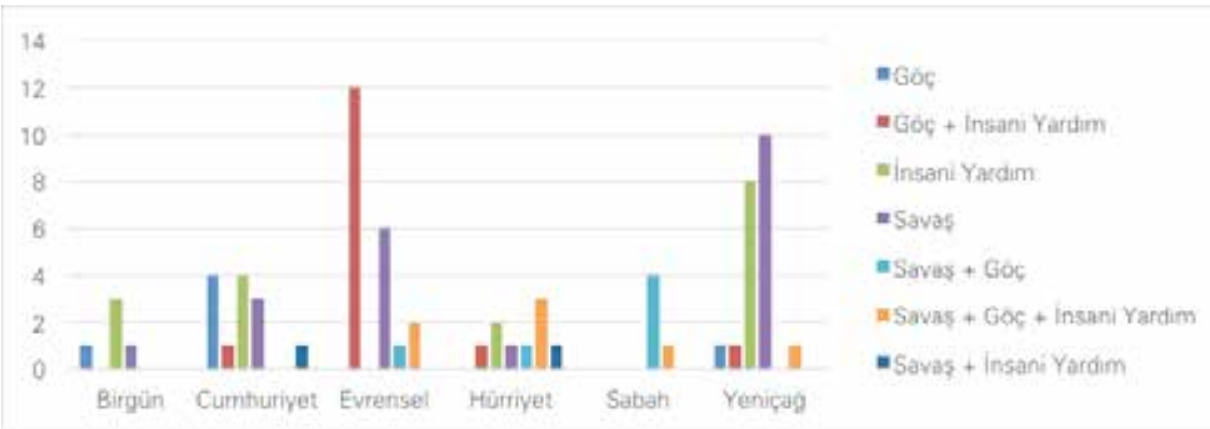

Altı farklı gazetede araştırmanın ele aldığı dönem içerisinde yayınlanan 74 adet haberin içeriği ve konusu incelendiğinde; 36 adet haberin savaşa ilişkin, 32 tanesinin göç ve insani yardıma ilişkin içerikte olduğu görülmüştür. Haberlerin içeriği farklı konuları ve bakış açılarını bir arada bulundurabildiği için, haberler iki konu grubunu içinde barındırabilmektedir. Yukarıdaki gruplandırma, gazetelerin Şengal'in işgalini takiben yaşanan olayları niceliksel olarak olayın hangi boyutuna ağırlık veren haberlerle aktarmayı tercih ettiğini özetlemektedir. Gazeteler olayı aktarırken, göç konulu haberlere, insani yardım haberlerine, göç ve insani yardım konularını bir arada içeren haberlere ve/ya savaş/çatışma konulu haberlere ağılık verirken, aslında gazetenin konuya bakış açısını ve tercih ettiği söylemi ortaya koymaktadır. İşale ilişkin çatışma ve savaşın ayrıntılarını aktaran içeriğe en fazla Evrensel ve Yeniçağ gazetelerinde rastlanılmıştır. Evrensel gazetesinin savaş içeriğine insani ve yardım ve göç ile birlikte yer vermesi dikkat çekerken, Yeniçağ gazetesinin savaş içeriğini insani konulardan ayrı olarak işlediği anlaşılmıştır. 
Tablo 3. Birinci sayfadaki konumlarına göre haberler

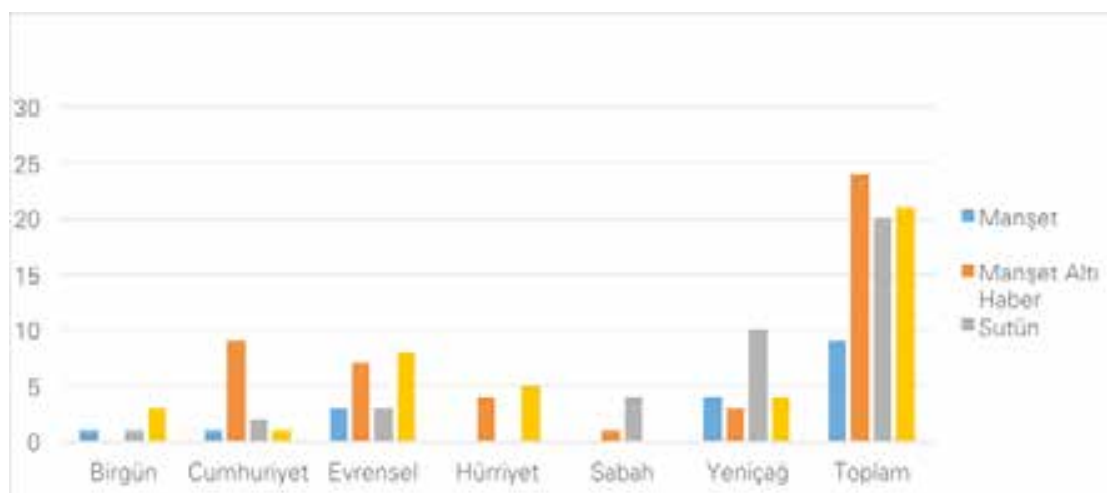

Haberlerin birinci sayfadaki konumlarına bakıldığında, sürmanşetten verilen toplamda 21 adet haberin 8 tanesinin Evrensel gazetesinde, 5 tanesinin de Hürriyet gazetesinde yer aldığı görülmektedir. Birinci sayfadan 21 adet haber yayınlayan Yeniçağ gazetesi ise, haberlerin yarısına yakınını (10 adet) sütun haber olarak vermiştir.

Tablo 4. İç sayfalardaki konumlarına göre haberler

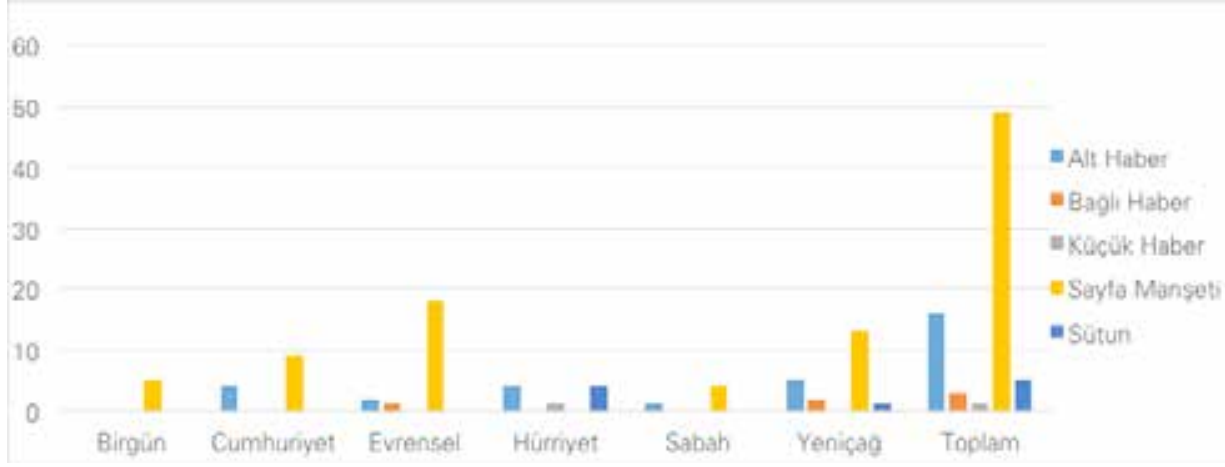

Haberler iç sayfadaki konumlarıyla ele alındığında, Evrensel'in birinci sayfada sürmanşet olarak yayınladığı haberlerin yanı sıra, iç sayfalarda da haberlere çoğunlukla sayfa manşeti olarak yer vermeye devam ettiği görülmüştür. Cumhuriyet' in ise 12 adet birinci sayfa haberinden, iç sayfaya taşınan 8 adet haber, sayfa manşeti olarak yer almıştır. 
Tablo 5. Kaynağına göre haberler

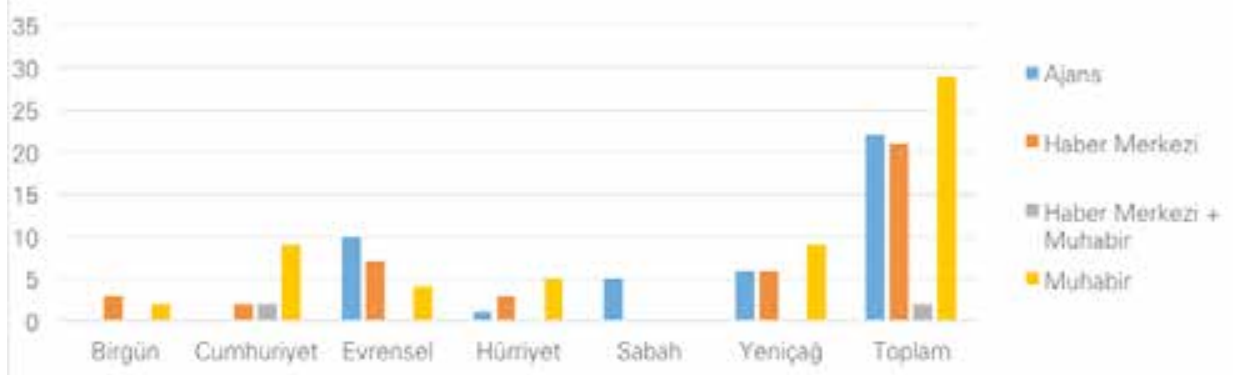

Haberlerin kaynağına göre sınıflandııımasına bakıldığında ise, Evrensel gazetesinin çoğunlukla ajans haberlerine yer vermesi dikkat çekerken, Yeniçağ ve Cumhuriyet gazetelerinin ise kendi muhabirleri aracılığı ile habere ulaştığı görülmüştür. Toplamda yapılan 74 haberin, 21 tanesi haber merkezleri, 29 tanesi muhabirler tarafından hazırlanmış, 22 tanesi de haber ajansları kaynaklıdır.

Olayı, 4 Ağustos 2014'te "Peşmerge çekildi IŞiD Şengal'e girdi" başlı̆ıyla sürmanşetten duyuran Evrensel, incelenen tarih aralığı boyunca konuyla ilgili 122 haber yapmış, bu haberlerin 21'i birinci sayfada yer almıştır. Gazete, 7 Ağustos 2014'te "Şengal'de direniş ve trajedi bir arada" başılıkı haberinden itibaren, savaş, göç ve insani yardım konularını çoğunlukla birlikte işlemeye başlamıştır. Türkmenler, Ezidilerle ilgili haberlerde ikincil unsur olarak yer alırken, Türkmenlerle ilgili yalnızca bir haber yapılmıştır. Ezidilerle ilgili haberler, IşiD ile Kürt güçleri arasındaki çatışmaların ayrıntılarını aktarmanın ötesinde olup, Şengal'in işgalinin ardından Ezidilerin yaşadıkları tüm aşamaları kapsamaktadır. Katliam, kadınların kaçırıması, köleleştirilmesi, Müslümanlığın dayatılması, kabul etmeyenlerin öldürülmesi, göç yolunda yaşadıkları açlık ve susuzluk, buna bağlı ölümler ve sağlık sorunları, Türkiye'ye girmelerinde yaşadıkları zorluklar, Türkiye'ye geldikten sonra kamplarda ve barındıkları yerlerde yaşadıkları sorunlar vb. haberlerde etrafıca işlenmiştir.

Evrensel gazetesinde yayınlanan haberler büyük oranda Kürt kaynaklarına dayandırılmıştır. Haberlerin çoğunluğu Dicle Haber Ajansı (DiHA) kaynaklıyken, başlıca diğer haber kaynakları; Fırat Haber Ajansı - Ajansa Nûçeyan a Firatê (ANF), BasNews Haber Ajansı, Ronahi TV, Al Arabiya, El Cezire'dir. Bunların yanı sıra, enformasyon kaynağı olan kişi ve kurumlar, yerel, muhalif ve mücadelenin içindeki unsurlardır: Demokratik Ezidi Hareketi Başkanı (TEVDA) Seid Hesen Seid, KCK Yürütme Konseyi Üyesi Zeki Şengali, Ezidi toplumu sözcüsü Cevher Ali Beg, Peşmerge Bakanlığı Sözcüsü Generel Helgurd Hikmet, YPG Basın Merkezi gibi. 
Incelenen haberlerin 7'si özel haber olup, bu 7 haberin 3'ü, DiHA'nın servis ettiği özel haberlerdir.

Birgün gazetesinde yayınlanan 5 haberin 3'ü savaş, 2'si göç konuludur. 4 Ağustos 2014 tarihinde Irak'ın Sincar bölgesinin IŞiD tarafından ele geçirilmesinin ardından başlayan Ezidi göçü, ilk olarak 16 Ağustos 2014 tarihi itibariyle gazetenin ilk sayfasında kendine manşetin altında yer bulabilmiştir. "Ezidi kadınlar köle yapılıyor, çocuklar susuzluktan ölüyor" başlığı taşıyan haber, Irak Parlamentosu Ezidi milletvekili Viyan Daxil'in beyanlarına ve Jinha ajansından Zehra Doğan'a dayandırımıştır. Haberlerden 18 ve 21 Ağustos tarihli olanlar muhabir imzasıyla yayınlanan özel haberler olup, diğerleri gazetenin haber masası tarafından yapılan derlemeyle hazırlanan rutin haberlerdir. Gazetenin veya muhabirlerin başvurdukları haber kaynakları kamplarda ikamet eden göç etmiş mağdurlar, Irak ve Irak-Kürt devletinin yetkilileri ve DiSK, KESK, TMMOB ve TiHV kurumlarıdır.

Ezidilerin göçü ile başlayan haber serisi, Birgün gazetesinin Ezidilerin Silopi ve Cizre'de konakladıkları kamplara muhabir göndermesiyle 18, 21 ve 23 Ağustos tarihlerinde tekrar gazetenin birinci sayfasında yer almıştır. Illk haber gazetenin muhabirinin kamptan görüştüğü Ezidilerle yaptığı söyleşilerden derlenmiştir. Takip eden 21 Ağustos tarihli haberde ise KESK, DiSK gibi emek örgütlerinin kamplara ziyareti ve ardından düzenledikleri basın açıklaması haberleştirilmiştir. 23 Ağustos tarihli haberde ise TiHV'in kamplar hakkında hazırladığı raporun ayrıntılı bir haberi okunmaktadır.

Konuya ilişkin toplamda 36 haber yapan Cumhuriyet gazetesinden incelenen 12 ilk sayfa haberinin 11'i özel haber niteliği taşımaktadır. Bölgeye giden Duygu Güvenç, Mahmut Oran ve Ceyda Karan'ın haberleriyle Ezidi ve Türkmenlerin yaşadıkları savaş, göç ve insani yardım boyutlarıyla aktarılmaktadır. Olay, 4 - 31 Ağustos tarihleri aralığında ilk ve bir defaya mahsus olarak 5 Ağustos 2014 tarihli "Kaçış Yolunda" başlıklı haber ile manşette yer almıştır. 6 Ağustos tarihli ilk sayfa haberinde ise Ezidilerin ön plana çıktığı görülmektedir; "500 Ezidi Katledildi" başlığıyla savaş resmedilmiş ve insani kriz aktarılmıştır. Mahmut Oral'ın bölgeden kaleme aldığı haberde, hem resmi yetkililere hem de kamplarda zor koşullar altında barınan Ezidilerin sesine yer verilmektedir. Haber, çatışmanın taraflarına ve savaşa değil, işgal/ç̧atışma sonrası yaşanan insani krize dikkat çekmektedir.

Cumhuriyet'in haberlerinde bölgedeki çok aktörlü yapıyı dikkate alan ve tarafların çoğuna söz hakkı vermeyi hedefleyen bir habercilik anlayışını görmek mümkündür. Haberler, en çok da yerel halkın sesine kulak vermesiyle ön plana çıkmaktadır. Gazete, bölgede yaşanan güçlükleri, yetkililerin beyanlarından aktarmaktan ziyade, birebir Ezidi ailelerle görüşme, yani haber kaynağını krizi birebir yaşamış gerçek kişilere dayandırarak aktarmayı tercih etmiştir. 
Hürriyet gazetesinde 9 haber, birinci sayfa haberi olarak sunulmuştur. Incelenen süre zarfında Ezidilerle ilgili haberler 6 gün gazete manşeti olmuştur. Haberler genel olarak savaş, göç ve insani yardım ana meselelerinin tamamı iç içe geçirilmiş olarak verilmiştir. Konuya ilişkin haberlerin ilki "Kritik üçgen için savaş" başlıklı 7 Ağustos 2014 tarihli haberdir. Haberlerin 5'i gazetenin muhabirlerinin imzasıyla yayınlanırken, Gülden Aydın imzalı bir özel haber dosyası, yazı dizisi şeklinde yayınlanmıştır. Konuya ilişkin yerel kaynaklar, haberlerde çokça kullanımış, kaynaklarının dağılımının dengeli olduğu görülmüştür. Örneğin Peşmerge Bakanlığı Genel Sekreteri Cabbar Yaver, Irak Türkmen Cephesi Yürütme Kurulu Üyesi Aydın Maruf Selim, Kızılay Genel Başkanı Ahmet Lütfi Akar, Beyaz Saray, Ezidi aktivist Ali Sincari, Diyarbakır Baro Başkanı Tahir Elçi, Irak Parlamentosundan Ezidi vekil Feyyan Dahil, CNN eski İstanbul muhabiri Ivan Watson, haberlerde enformasyon kaynağı olarak kullanılmıştır. Haberlerin tümünde görsel yer almaktadır.

Sabah gazetesinde konuya ilişkin 5 haber yer almaktadır. İşgalle ilgili ilk haber, 5 Ağustos 2014 tarihli "Sincar'da büyük trajedi: IŞiD 250 bin kişiyi yerinden etti" başığıyla, kendine birinci sayfanın en alt küçük sütununda yer bulabilmiştir. Diğer haberlerde aynı durum söz konusudur. "Erbil'e dayanan IşiD Kürtler'le savaşıyor" (7 Ağustos 2014), "ABD Sincar'daki Yezidiler'in tahliyesinden vazgeçti" (15 Ağustos 2014) ve "Yezidi kadınları 150 dolara sattılar" (16 Ağustos 2014) tarihlerinde de tekrar etmiştir. Bu beş gün arasından yalnızca 10 Ağustos 2014 tarihinde "10 bin Yezidi kurtuldu" başlığıyla verilen haber, manşetin hemen altında yer alarak diğer günlerden ayırılmıştır. Haberlerin devamı ise, ya "Dış Haberler" ya da "Dünya Raporu" bölümlerinde yer almaktadır. Bu sayfalarda 5, 7, 15 ve 16 Ağustos 2014 tarihlerinde en büyük başlıkla devam eden haberler, 10 Ağustos 2014'te alt başlıkla ve daha küçük olarak sunulmuştur.

Yeniçağ incelenen ilk günden itibaren, Türkmen vurgusunu gitgide artırarak, Sincar'ın işgali ile en çok etkilenen etnik gruplar olarak, Ezidiler ve Türkmenlerin mağduriyetleri, bu grupların IŞiD'in silahlı müdahaleleri ile göçe zorlanması konularına ağırlık vermektedir. Yeniçağ, Sincar'ın IŞiD tarafından işgalini, Türkmenleri merkeze alarak ilk sayfadan yayınladığı 21 haberle duyurmayı tercih etmiştir. Zaman zaman Ezidilerin yaşadığı mağduriyete de insani değerleri göz önünde bulundurarak değindiği görülmekte, ancak bu haberlerde de Türkmenler merkez konumunu korumaktadır. Yeniçağ'ın Sincar üzerine yaptığı haberlerde yoğun olarak, başta Irak Parlamentosu Türkmen Milletvekilleri olmak üzere, Türkmenlerin görüşlerine yer verdiği, Ezidilerin görüşlerine hiç yer vermediği görülmektedir. Uluslararası ve yerel kaynaklarda yer alan haberlere, Türkmenlere yapılan haksızlıkları vurgulama çerçevesinde yer verilmiştir.

\section{Olayın sunumu ve aktörlerin temsili}

Olay tüm gazetelerde çatışmadan ziyade, "IŞiD saldırısı sonrası yaşanan insani kriz" bağlamında aktarılmıştır. IşiD'in herhangi bir açıklaması veya 
duyurusu, haberlerin içerisinde yer almamıştır. Bunun yanında; kulak verilen ses, çatışmanın karşı tarafını oluşturan silahlı güçler, ordular ve direniş gösteren ya da göçe zorlanan topluluklardır. Doğal olarak bu durum, çatışmanın taraflarına dair dengeli miktarda olumlu ya da olumsuz olgular sunmayı ve öznel ifadelerden kaçınmayı engellemiştir.

Evrense/ gazetesi süreci, 2012'de Rojava'da özerklik ilan eden Kürt siyasal hareketi bağlamında ele almıştır. Ezidiler, çoğunlukla yaşadıkları mağduriyetle temsil edilmişse de, verdikleri yaşam mücadelesi de ön planda tutulmuştur. Ezidiler öldürülmüş, katledilmiş, işkence görmüş, IşiD zulmünden kaçmak için açlık ve susuzluğu göze alarak yola çıkmışlardır. Özellikle Ezidi kadınları; tecavüze uğrama, kaçırıma, köleleştirilme ve köle pazarlarında satılma tehlikesi altındaki mağdurlardır. Ancak Ezidi kadınları, aynı zamanda, açlık ve susuzluktan en çok etkilenen çocuklarını hayatta tutmak için parmaklarını kesip kanlarını içiren, bu yönüyle ölüme direnen aktörlerdir. Tüm mağduriyetlerine rağmen Ezidiler, silahlı direniş birlikleri kurarak IŞiD'e karşı mücadeleye katılan aktörlerdir. IŞiD; katil, insanlara zulmeden, kadınları kaçıran, köleleştiren, satan, kentleri ve köyleri talan eden, yağmalayan, insanlara işkence yapan bir aktördür.

IŞiD, Birgün gazetesinde de kadın satan ve tecavüzlerde bulunan bir aktör olarak temsil edilmektedir. Cumhuriyet'te IŞiD için "terör örgütü IŞiD militanları" gibi ifadeler kullanıldığı görülmüștür. 4 Ağustos 2014 tarihli "Türkmenler kapıdan giremiyor" başlıklı haberde, IŞiD'den kaçan Türkmen ve Ezidilerin Duhok ve Zaho'ya sığındığı belirtilmiştir. Haberde IşiD, olayın "kötü" aktörü olarak temsil edilmiş, Evrensel'deki duruma paralel olarak, Türkiye'nin ise sığınma taleplerini yanıtsız bıraktığına dair iddialara yer verilmiştir. Gazetede Kürt güçlerine söz hakkı tanınmış, Irak Türkmen Cephesi (ITC), Kürdistan Yurtseverler Birliği (KYB), Halk Savunma Birlikleri (YPG), Beyatı aşireti gibi tarafların açıklamalarına yer verilmiştir.

Sincar Dağı'nda gerçekleşen çatışmalardan etkilendiği gündeme gelen iki grup vardır; Ezidiler ve Türkmenler. Hürriyet gazetesinde Ezidiler ilk sayfada 9 haberde yer bulmuşken Türkmenler ilk sayfada hiç yer almamıştır. Gazetelerin siyasal konumlarını ele alırken ana akım olarak işaretlediğimiz Hürriyet gazetesinin Türkmenlere ilk sayfada hiç yer vermemesi bu iki etnik gruptan Ezidileri daha çok sahiplenmesi olarak yorumlanabilir.

Sabah gazetesinde dikkati çeken önemli bir unsur, Türkmen ve Ezidiler arasında bir ayrım yapılmadan, her ikisinin de aynı şiddet kaynağından zarar gören taraflar şeklinde temsil edilmesidir. Diğer bir deyişle, hükümete yakınlığıyla bilinen bu gazetenin ideolojik bir tutumla sadece Türkmenlerin yaşadıklarına odaklandığını gösteren bir bulgu yoktur.

Yeniçağ, işgal sonrası göçe zorlanan tarafların Türkiye'ye gelişi ile ilgili, Ezidilerin ve Türkmenlerin karşılaştığı muameleyi karşılaştırarak, Ezidilerin 
kolayca Türkiye'ye giriş yapabildiğini ancak Türkmenlerin pasaportlarının olmadığı, pasaport sürelerinin dolduğu gibi gerekçelerle Türkiye'ye girişlerinin zorlaştııldığını belirtmektedir. Burada Türkmenler, diğer bir etnik grup ile karşılaştırılmakta, Türkmenlerin mağduriyeti vurgulanmaktadır. "Türkmen değil insanlık ölüyor", "Türkmen ölümüne direniyor, Türkiye Yezidi'yi görüyor!..", "Kapılar pasaportlu Türkmen'e de kapalı", "Türkmenler sahipsiz" başlıklı haberlerde, IŞiD teröründen mağdur olan 50 bin kişinin uluslararası toplumdan ve Türkiye'den destek gördüğü, ancak Türkmenlerin sahipsiz bırakılarak hiçbir destek görmediği konusu tekrar tekrar işlenmiştir.

\section{Görsellerin kullanımı}

Görsellerin kullanım biçimlerine bakıldığında ise, "kurbanlaştıııı" ya da "şeytanlaştıııı" yaklaşım, kendini belli etmektedir. Oysa bu durum; aşırı duygusallık, ya da şeytani bir düşman olgusuna duyulan korkuyu beslemesi bakımından barış gazeteciliği önermeleri ile kesinlikle örtüşmemektedir. Dolayısıyla ortaya çıkan durum, çatışmanın taraflarına dair "iyi-kötü", "kahramanhain" etiketlemesinin yapıldığı propaganda odaklı bir yaklaşıma işaret etmektedir. Ayrıca gazetelerin, çatışma bölgesinde muhabiri bulunmadığı için, güncel olmayan arşiv kaynaklı ve olayın aktörlerinin stereotipleştirildiği fotoğrafları kullandığı gözlenmiştir.

Evrensel, haberlerde kullandığı görsellerle, IşiD karşısındaki mücadeleyi ve IŞiD'in mağdur ettiği Ezidilerin yaşadığı insani krizi vurgulamıştır. IŞiD'e dair görsel kullanılmazken, IŞiD'in konu edildiği haberlerde, karşıtı üzerinden temsil edildiğini söylemek mümkündür. Örneğin; IŞiD'le savaşan Kürt güçleri, tankların üzerindeki militanlar, zafer işareti yapan silahlı güçler, yürüyerek bölgeden uzaklaşan, kayıkla kaçan Ezidiler, yaşı Ezidi kadınları, çadırlarda ve kamplarda kötü koşullarda yaşayan Ezidi çocukları, Türkiye sınırında bekletilen ve askerin saldırısına uğrayan Ezidiler, yorgunluk ve susuzluk nedeniyle hayatını kaybeden Ezidilerin portreleri, muayene edilen Ezidiler. Ezidilerin yaşadığı insani kriz tüm boyutlarıyla gösterilmek istenmiş, kurbanlaştırmanın aksine, Ezidiler, "vahşet karşısında savaşmayı seçen özne" olarak resmedilmiştir.

Birgün gazetesinde tüm haberler yer aldıkları iç sayfada en büyük haber olarak yerleştirilmiş ve imzasız görsellerle her haber desteklenmiştir. Bu görsellerin hepsinde Ezidi olduğu tahmin edilen göç halindeki bir ahali fotoğrafı mutlaka kullanılmış, kamplardan derlenen hikâyelerde ise kamplarda kalan Ezidiler görsel içerik olarak kullanılmıştır.

Cumhuriyet' in haberlerinde Ezidiler etnik kıyafetleriyle ve kadının ön planda olduğu görsellerle temsil edilmiştir. Kadının ailedeki rolüne vurgu yapılırken, günlük hayatta çocuklarıyla çektiği eziyet resmedilmiştir. Bu da, dramatizasyon öğesini besleyen unsur olarak karşımıza çıkmaktadır. Haberlerde, savaşın yollara 
düşürdügü anneler ve çocuklar hikâyeleştirilmiş ve kadın kucağında bebeği, ya da günlük hayatta çocuklarıyla verdiği mücadele ile tasvir edilmiştir.

10 Ağustos'ta dış haberler servisinin düzenlediği haberde “Ölümden kaçış sürüyor" başlığıyla yaşanan göçün anlatımında dramatik bir anlatım tercih edilirken, görsellerde kıyafetlerin farklılığı göze çarpmaktadır. Böylece, "biz" öznesi icat edilerek ötekileştirilen Ezidilerin bizden olmadığına vurgu yapılmış ve "onların", misafirperver "biz" in yardımına muhtaç olduğu iddia edilmiştir. Gazetede, Türkiye'nin kapılarını açmasına ilişkin haberler, bu tondaki haberlere örnek olarak gösterilebilir.

16 Ağustos tarihli "Zaho ve Duhok'ta insanlık trajedisi yaşanıyor" sürmanşetiyle çıkan haberde yine bir kadının, annenin özürlü çocuğuyla çektiği sefalet anlatıııken, insanlığın artık sınırına gelindiği, kadınların ve çocukların savaşın vahşetinde kurban oldukları vurgulanmıştır. Anne çocuğu yıkamaktadır; zor koşullar altında yaşamak durumunda bırakılan bir halk. Kadınlar ise yine günlük yaşamı sürdürmenin ve yaşama bağlı kalmanın aktörleri olarak temsil edilmişlerdir.

Savaş; krokiler yardımıyla reel dünyanın dışında tasvir edilmiş, örneğin "savaş" denildiğinde, uçak, Peşmerge, silah, tank ve çöl gibi görsellerden faydalanılmıştır. Ayrıca haberi çekici kılabilmek adına genellikle hikâyeleştirme stratejisine başvurulmuştur. 17 Ağustos tarihli haberde; manşette savaş krokileri kullanılırken, iç sayfada; başlık "Peşmerge kara harekâtına hazırlanıyor" şeklindedir ve böylece "savaş kapıda" gösterilirken, görsel çocuklu anneleri işaret etmektedir. Bu da, haberi çekici kılan unsur olarak anne-çocuk imgesinin kullanıldığını ortaya koymaktadır.

Görsellerin hiçbirinde imza bulunmayan Hürriyet'te parçalı halde küçüklü büyüklü birçok görsel kullanılmıştır. Görsellerin bir kısmında ellerinde silahlar olan askerler bulunurken, diğer kısmında kadınlar ve çocuklar vardır. Kadınlar ve çocukların toplu halde kaçış yahut sığındıkları noktalardaki savunmasız halleri ağırıktadır. Görsellerdeki kurbanlaştıııcı görüntüler, altlarına yazılan bazı cümleler ile pekiştirilmiştir. Örneğin; "Seno Süleyman, kucağında bir yaşındaki bebeği Sehran, iki çocuğu Cuacher (4) ile Faysal öylece bakıyor. ", "Katliama ağlayan vekil de yaralı".

Sabah gazetesinde ise haber fotoğraflarında, kurbanlaştıııcı bir duygusalık göze çarpmaktadır. Özellikle çekilen acıları, yaralanmış bedenleri yansıtan fotoğraflar kullanılmıştır; güvenlik koridorundan yürüyen Ezidiler, kurtarılan yaşlı kadın, çocuk ve adam gibi. Buna karşılık Ezidilerin kurbanı olduğu olarak temsil edildiği savaşın diğer aktörleri için şu görseller kullanılmıştır: ABD tankı, silahlı IŞiD üyeleri, Silahlı Peşmerge birliği, direnen Türkmenler. 
Yeniçağ gazetesinde, bir haber haricinde tüm haberlerde görsel kullandığı görülmektedir. Görsellerde daha çok göç eden insan grupları, kamplarda yaşayan Türkmenlerin içinde bulunduğu olumsuz yaşam koşulları yer almaktadır. Türkmen milislerin silahlı mücadelesinin anlatıldığ haberlerde, elleri silahlı Türkmen milislerin fotoğrafları görülmektedir. Görsellere eşlik eden alt metinlerde, "IŞiD katliamından kaçan ve sayıları 50 bine ulaşan Yezidiler, yaşadıkları bölgeleri terk ederek Irak'ın kuzeyindeki Duhok kentine göç etmeye başladı.", "Ortadoğu'da hızla büyüyen kanlı IŞiD örgütünün eylemlerinden en çok Türkmenler zarar gördü. Türkmenlerin bir bölümü Sincar Dağı'na sığındı", "Terör örgütü IŞiD'in katliamından kaçan Türkmen soydaşlarımız, sağılı açısından oldukça yetersiz kamplarla hayata tutunmaya çalışıyor.", "Telafer'den kaçıp Sincar Dağı'na sığınan 2 bin Türkmen, Yezidilerle birlikte aç susuz ölüm kalım mücadelesi vererek kurtarılmayı bekliyor.", ifadeleri ile Ezidilerin yanında Türkmenlerin varlığına vurgu yapılmakta ve çoğunlukla aynı durumda betimlenen bu iki halk arasında Türkmenlerin mağduriyetinin altı çizilmektedir.

\section{Mikro yapılar}

Van Dijk'in mikro yapı analizi; sentaktik analiz, bölgesel uyum, kelime seçimleri ve retorik analizi kapsamaktadır. Haber metinlerinde kullanılan kelimeler de ideolojik yapılanmanın anlaşılması açısından mikro yapı içinde analiz edilirken, kelime seçimleri, aktörler hakkındaki inanç ve ideolojiler ortaya koyar niteliktedir (Doruk, 2013, s. 115).

\section{Kelime seçimleri}

Haberin temel unsurları olan mekân ve aktörlere dair isimlerin aktarılmasında bile gazetelerin yaklaşımları arasındaki farklılıklar göze çarpmaktadır. Örneğin Evrensel ve Birgün, saldırının mekânını, bölgesel ismi olan "Şengal" olarak sunarken; Sabah, Hürriyet ve Yeniçağ, Türkçede geçen haliyle "Sincar"। kullanmıştır. Cumhuriyet gazetesi ise iki kullanıma da yer vermiştir. Birgün, Cumhuriyet ve Hürriyet, metinlerde "Ezidi" kelimesini tercih ederken; Evrensel, söz konusu halkın kendini tanımlama biçimine hassasiyet göstererek, kelimeyi "Êzidi" olarak kullanmıştır. Öte yandan Yeniçağ ve Sabah gazeteleri ise karşı konumlanmanın tanımı olan "Yezidi" yi kullanmaktadır.

Evrensel gazetesinin haberlerinde aktörlerin temsilinde kullanılan kelimelerin, gazetenin ideolojik tutumuyla birebir doğru orantılı olduğu görülmüştür. Gazete, Kürtçe konuşan bir halk olan Ezidileri, ana dillerindeki gibi "Êzidiler" şeklinde temsil eden tek gazete olmuştur. IŞiD için düşmanlaştırıcı ifade kullanılmamış; ancak işgali altındaki bölgelerde yaptıkları aktarılarak IŞiD karşısındaki mesafe net bir şekilde korunmuştur. "IŞiD militanları" ifadesinin çok nadir kullanıldığı görülmüş; haberlerde yalnızca "IŞiD" ismi kullanılarak ekstra yönlendirme yapılmamıştır. Buna karşılık Kürt güçleri ve Ezidilerin IŞiD karşısındaki mücadelesine ilişkin olumlayıcı kelimeler çokça kullanılmıştır; "direniş", "gerilla", 
"savaşçı", "militan" gibi. Örneğin "Şengal'de direniş ve trajedi bir arada" (7 Ağustos 2014) başlıklı haberde, "direniş" ve "trajedi" kelimelerini bir arada kullanarak, trajediye karşı gelmenin yolunun "direniş"ten geçtiği vurgulanmıştır.

Birgün gazetesi, 17 Ağustos 2014 tarihli haberini “Erdoğan'ın unsurları yine katliam yaptı" başlığıyla vermiştir. Haberde IŞiD üyelerinin Şengal'in en büyük köylerinden biri olan Kojo'da yaşayan Ezidilere "Ya Müslüman olun ya da ölün" diyerek baskı yaptığı ve halkın bunu reddetmesi üzerine 80 kişinin öldürüldügü bir katliamın gerçekleştirildiği belirtilmiştir. Olay bir sebep sonuç ilişkisine dayandırılarak aktarılmış olsa da, haberde dikkati çeken nokta Birgün gazetesinin, IŞiD mensuplarını tanımlarken, "Erdoğan'ın unsurları", "militanlar", "milisler" gibi ifadelere başvurmasıdır. Söz konusu ifadeler, barış gazeteciliğinin ilkeleriyle çelişmektedir; çünkü burada hem "etiketleyici" hem de "suçlayıcı" bir tavır vardır. "Erdoğan'ın unsurları" nitelemesi ile IŞiD ve Türkiye arasında bir bağlantı olduğu anlatımak istenirken, bu ifade "IŞiD'e destek olmak için Türkiye'ye ödeme yapıldı" alt başlığıyla güçlendirilmeye çalışılıışır. Ancak kaynak olarak sadece Katarlı muhaliflerin bilgisine yer verilip, birden çok kaynağa başvurulmaması, iddianın suçlayıcı yönünü ortaya koymaktadır. Bu durumda kaynakların dengeli kullanımından bahsedilemeyeceği gibi, hızlı bir etiketleme ve suçlama sebebiyle çözümden yana bir dilin varlığından söz etmek de zordur.

Birgün muhabirinin Silopi ve Cizre'deki kamplarda kalan Ezidilerle görüşerek tanıklıklara dayalı haberi, ajitasyon yönü kuvvetli ara başlıklarla hikâyelendirilmiştir: "Saldırıya uğradık, çok insan öldü", "Çocuklar annelerini soruyor", "Ölüm kolay ama çocuklar var", "Erkekleri canlı canlı gömdüler", "Bir daha dönmeyiz" gibi. Kamplara ilişkin yapılan devam haberlerinde Ezidiler; "sığınmacı" ve bir haberde "yurttaş" olarak, yani "biz" ve "öteki" olarak konumlandırılmıştır.

Cumhuriyet gazetesinin 5 Ağustos 2014 tarihli birinci sayfadan "Kaçış Yolunda" başlığıyla verilen haberin başlığı iç sayfada "Katliamdan Kaçış" olarak değişmiştir. Haberin spotunda kullanılan "katliam" ve "canını kurtarmak" gibi ifadelerle, şiddetin tarafları ve görünen yüzü ön plana çıkarılırken, şiddetin görünmeyen yüzü ikinci planda ele alınmıştır. 16 Ağustos 2014 tarihli "Kucağında felçli kızı 7 gündür dağlarda" başlıklı sürmanşet haberin spotunda "Zaho ve Duhok'ta insanlık trajedisi yaşanıyor" ifadesi kullanılmıştır. Haberin içeriğinde IŞiD'in "vahşeti" ve Ezidilerin yaşadığı "insanlık trajedisi" ifadelerine yer verilmiştir.

Sincar - Şengal kullanımını ilk sayfada bu kez birlikte görmek mümkündür; "Sincar" (Şengal) denildikten sonra haberin iç sayfadaki devamında kullanım detaylandırılmıştır: "... Kürt ve Ezidilerin 'Şengal', Arap ve Türkmenlerin 'Sincar' olarak adlandırdıkları...". Gazete Sincar/Şengal kullanımında, farkıı̆ığın kökenini birkaç haberde belirtmekle birlikte Sincar Dağı ifadesini esas kullanım olarak benimsemiştir. Özellikle ilk sayfada Şengal ifadesine ya parantez içinde yer 
verilmiş ya da hiç kullanılmamıştır. Bu da gazetenin ulusalcı geleneği devam ettiren sol-merkez olarak işaretlenebilecek siyasal konumuna dair ipucu vermektedir.

Hürriyet'te yer alan haberlerin 2'si hariç tamamının başlığında "Üçgen savaşı", "Vur emri", "Gel kocanın kafasını al" gibi savaş ve şiddet sözcükleri kullanılmıştır. Habere dikkat ve ilgi, şiddet sözcüklerinin çarpıcılığı ile çekilmeye çalışımıştır. Yaşanan olayların sunumunda savaş ve şiddetin görünür sonuçlarına odaklanılmıştır. Savaşın nedeni IŞiD'in vahşeti olarak sunulmuş, yaşanan olaylar tarihsel bir açıklama ile ele alınmamıştır. Herhangi bir açıklamasına yer verilmeyen IŞiD, "katliam" "vahşet" gibi şiddet sözcükleri ile birlikte şeytanlaştırıcı bir dil ile betimlenmiştir. Diğer taraf olan Ezidi halkının yaşadıkları ise "IŞiD'ten kurtulan hastalıktan ölüyor", "Köprüye varan hayatta kalıyor", "50 derece sıcakta can pazarı" gibi ifadelerle aşırı duygusallaştııııı bir şekilde aktarılmıştır.

Sabah gazetesi, bir topluluğun kabul gören ve resmi isimleri olan "Ezidi" yerine, "Yezidi" ifadesini kullanmıştır. Gazetenin, Ezidilerin rahatsız oldukları "Yezidi" ifadesini ısrarla kullanması, düşündürücüdür. IŞiD'den bir "terör örgütü" olarak bahsedilmesi veya IŞiD'liler için militan sözcüğünün kullanılması da bu yapılanmaya yönelik bakış açısını ortaya koymaktadır. Haberlerinde savaş ve çatışma ön planda olan Sabah gazetesi, çatışmanın görünür sonuçlarına ve şiddete dair detaylara odaklı bir tutum izlemiştir. Böylelikle, IŞiD'in Ezidi ve Türkmenlere uyguladığı şiddeti ana eksene alarak, zorlandıkları göçü ve göç sırasında gerçekleşen ölümleri, en zorlu şartlar altında hayatta kalma mücadeleleri olarak dramatize edip, kurbanlaştırıı bir dil kullanmıştır. 16 Ağustos 2014 tarihli haberde ise, Irak'tan kurtarılarak Fransa'ya getirilen Ezidi bir ailenin, basının karşısına geçerek, IŞiD'in Musul'da kurduğu insan pazarında 700 Ezidi kadını ortalama 150 dolara sattığına dair açıklaması aktarıımıştır. Haberde olayın tanıklarının ifadesine başvurulmasını olumlu bir tutum olarak değerlendirmek mümkündür. Ancak haberin başlığının, "Ezidi kadınları köle gibi sattılar" gibi kurbanlaştırıcı bir söylem içinde sunulması, yine yalnızca şiddetin görünür ve trajik neticelerini vurgulamaktadır.

Yeniçağ da Ezidiler için "Yezidiler" kelimesini kullanarak, bu topluluğun kendini ifade ediş biçimi karşısındaki tutumunu net bir şekilde göstermiştir. Gazetede Türkmenler dışındaki tüm diğer etnik ve uluslararası grupların ötekileştirildiği bir dil baskın haldedir. IŞiD bir "terör örgütü" olarak tanımlanmakta, Türkmenlerden ise "Türkmen soydaşlar" olarak bahsedilmektedir. Ezidiler ise, gazeteye göre zaten Müslüman olmadıkları için IŞiD'in hedefinde olan bir etnik gruptur.

Yeniçağ, işgal ile Sincar ve Kuzey Irak bölgesinde gerçekleşen zorunlu göçün, IŞiD tarafından "kâfir" olarak görülen Ezidilerin bölgede yaşamasından kaynaklandığını ve Ezidiler yüzünden Türkmenlerin de tehlike altında olduğunu vurgulamaktadır. Bu noktada gazetenin söylemi "insani kriz" bağlamından uzaklaşarak aynı topraklarda yaşayan Ezidilerin ötekileştirildiği, hatta IŞiD'in silahlı mücadelesinin Türkmenleri etkilemesinin asıl sorumlusunun Ezidiler 
olduğunu işaret eden bir hal almaktadır. Ancak aynı şekilde Şii olmalarından, yani inançlarından dolayı IŞiD'in hedefi haline gelen, Türkmen kasabası Emirli'deki çatışmalarda Türkmen milislerinin yalnız kalması ve hiçbir destek olmadan iki aya yakın süredir IŞiD'e karşı "tek başına direnmesi" öne çıkarılmıştır. Yeniçağ'ın haberleri "ırka" bağlı olarak farklı yorumladığı ve yansıttığı, söylemin IŞiD'e maruz kalan topluluğun kimliğine bağlı olarak değiştiği görülmektedir.

\section{Haberlerin retoriği}

Evrensel gazetesinde analiz sonucu elde edilen en önemli bulgulardan biri, Şengal Dağının işgal edilmesi olayı ve sonuçlarını, Kürt siyasal hareketi kapsamında değerlendirilmiş olmasıdır. Haberlerin büyük çoğunluğunun Dünya sayfası yerine Doğu-Güneydoğu sayfasında verilmiş olması, bunun başlıca göstergesidir. Haberlerde Kürt hareketinin Türkiye'deki temsilcileri, Rojava, IŞiD’le çatışmalar ve Şengal Dağı işgali arasında bağlar kurulmuş ve bu konular, bir bütünlük içinde ele alınmıştır. Incelenen konu, Kürt sorunu ve Suriye iş savaşına ilişkin resmi politikaların bir sonucu olarak değerlendirilmiş, Türkiye'deki Kürt sorunundan yalıtılmamıştır. Yapılan haberler, IŞiD'e karşı Kürt mücadelesinin meşruluğunu olumlar biçimdedir. Ezidilerin, bu açıdan da gazetenin başlıca gündemleri arasında yer almış olması muhtemeldir.

Evrensel gazetesinin konuyla ilgili haberleri, IŞiD'e karşı Kürtlerin mücadelesini olumlar niteliktedir. IŞiD, bölgede yaşayan halkların ve kültürlerin, özellikle de kadınların varlığını tehdit eden bir aktör olarak değerlendirilmekte; buna karşı verilen mücadele ise meşru görülmektedir. Olay Türkiye'nin sınırlarında yaşanmış olsa da iç politikadan ayrı görülmemiş; gazetenin sosyalist duruşu, konunun değerlendirileceği politik hat üzerindeki belirleyici olmuştur.

Evrensel'in haberlerinde Türkiye'deki devlet kurumları da, IŞiD'den sonra Ezidileri mağdur eden aktörler olarak temsil edilmiştir: Pasaportu olmayanlar için "geçirmeyin" emri veren Valilik, Ezidileri sınırda bekleten, biber gazlı ve silahlı saldırıda bulunan asker, Ezidilere sağlık hizmeti vermeyen Sağlık Bakanlığı... Buna karşılık Halkların Demokratik Partisi'nin yönetiminde bulunduğu Silopi, Cizre ve Viranşehir belediyeleri ile kitle örgütleri, Ezidilere yardım eden, onlarla dayanışma içinde olan kurumlardır. Bölgedeki Kürt güçleri ise; IŞiD'e karşı meşru mücadele halindeki güçlerdir ve diğer gazetelerden farklı olarak tüm örgütlerin isimlerine kısaltmalarının açıklamalarıyla birlikte yer verilmiştir. PKK'nin temsili ise; diğer Kürt güçlerinden de destek isteyen Ezidilerin IŞiD'e karşı yardım istediği ve bu yardım karşısında minnettar olduğu, Suriye'deki Kürt güçleriyle birlikte hareket eden bir örgüt olduğu yönündedir.

Haber kaynakları yönünden ise Birgün gazetesi yalnız resmi ağızlara değil, şiddetin sıradan mağdurlarına da kendilerini ifade hakkı tanımıştır. Ancak gerçek tanıklıklardan derlenen haberler, halk odaklı olmaktan ziyade şiddeti dramatize edici eğilime sahiptir. Zaten kutsal savaşın zafer vadeden grubu da birleşik Kürt 
silahlı güçleridir. Bu silahlı güçlerin resmi kaynaklarında sürekli zafer vaadinde bulunulmakta ve gazete de bu beyanatları çözümü ancak zaferde gören bir söylemle düzenlemektedir

Sabah gazetesinde 7 Ağustos 2014'te, ilk sayfada en küçük sütunlardan birinde verilen haber, Dünya Raporu bölümünde devam eden yarım sayfalık yeriyle Ezidi ve Türkmenlerin çaresizliğini gündeme taşırken aynı zamanda Bağdat'ın 160 km kuzeyindeki Amerli bölgesinde bulunan 34 köyün tamamını ele geçiren IŞiD'in "engellenemez" ilerleyişi karşısında Türkmenlerin "zayıf" direnişinden söz etmektedir. Çatışma sahası ise IŞiD karşısında Peşmerge, PYD, PKK güçleri ve Irak ordusunun devreye girmesiyle daha net bir biçimde iki tarafa ayrıı. Bu haberde dikkat çekici bir nokta ise olayın zarar gören taraflarından biri olan Ezidilerin, Habur Sınır Kapısı'ndan Türkiye'ye giriş yaptıktan sonra Anadolu Ajansı'na yaptıkları açıklamalara yer verilmesidir. Bu şekilde yalnızca resmi kaynakların kullanıldığı elit odaklı bir anlayıştan ziyade, çatışmadan etkilenen sıradan insanların sesine de gazetede yer verilmiş olması olumlu bir yaklaşım olarak ortaya çıkar.

IŞiD'in saldırıları sonrasında Musul kentindeki Sincar Dağı'nda bir hafta mahsur kalan binlerce Ezidinin, karadan oluşturulan güvenlik koridoruyla kurtarılmaya başlandığını haber veren 10 Ağustos 2014 tarihli haberse, olaya yapılan insani destek ve yardımı vurgulaması açısından önemlidir. Hatta Ezidi kökenli milletvekili Vian Dakhil'in AFP ajansına "Hâlâ binlerce Yezidi dağlarda sıkışmış durumda. Eğer bir ya da iki gün içinde ulaşımazsa yüzlercesi açlık ve susuzluktan ölecek" şeklindeki açıklamasına yer verilmesi, olayların kamuoyu tarafından sadece katliam ve çatışma olarak algılanmasını engellemekte ve yaşananları daha insani bir yönden sunmaktadır.

Sabah gazetesi, "Sincar'da büyük trajedi: IŞiD 250 bin kişiyi yerinden etti" (5 Ağustos 2014) başlıklı haberde, özellikle 88 Ezidi erkeğinin toplu şekilde infaz edilmesi anlatılmış, IŞiD'in bölgede Ezidilerin ziyaret ettiği türbe ve dini mekânları da yakıp yıktığı ve tüm bunların karşısında Peşmerge'nin hiçbir varlık gösteremediğine vurgu yapılmıştır. Peşmerge'nin pasif halinin krizi derinleştirdiği, bunun neticesinde IŞiD'i durdurabilecek hiçbir gücün olmadığı belirtilirken, burada bu çatışma odaklı haberin IŞiD'i bölgenin "şeytani" ve "yenilmez" gücü ilan ederek onun söz konusu gücünü "yücelttiğini" söylemek mümkündür. Ayrıca, çözüm odaklı bir yaklaşıma rastlanmadığı gibi, silaha/silahlanmaya vurgu yapılarak şiddetin yaralı ve ölü sayısı gibi maddi zararlarını ön plana çıkartmaktadır.

Yeniçağ'ın 5 Ağustos'ta Sincar'ın işgali ile ilgili, "iktidar Türkmenlere kinli" başlıkı haberinde, Türkiye hükümetinin Türkmenlere destek vermekten kaçındığını söylemekte, haber iç sayfada "Suriyeliye geçiş serbest bize ise pasaport şart" başlığı ile verilmektedir. İç sayfadaki haberde, Türkmenler, Suriye'deki savaştan etkilenerek Türkiye'ye göç etmek zorunda kalan Suriyelilerle karşılaştırılmakta, Ezidilerle yaptığı karşılaştırmada olduğu gibi Türkmenleri kurbanlaştırmaktadır. 
Yeniçağ'da Türkmenlerin mağduriyetinin anlatıldığı haberlerin yanı sıra, Sincar'ın IŞiD tarafından işgali sonrasında uluslararası toplumun bölgeye verdiği desteğin, ABD'nin insansız uçaklar ile müdahalesi ve bölgedeki Peşmergelere verdiği desteğin ileride PKK üzerinden Türkiye'ye karşı kullanabileceği konusunda görüşlere yer vererek, konuyu Türkiye'nin iç güvenlik sorunsalı olarak görmeye ve yansıtmaya başlamıştır. "Türkmen Katliamında İsrail Oyunu", "Petrol Bölgesinde Etnik Operasyon", "Musul Barajı için ABD-Kürt ittifakı", "PKK'ya silah var Türkmen'e niye yok?" başlıklı haberlerinde, Sincar'ın kurtarıması ve IŞiD etkisin azaltılmasına ilişkin müdahalelerin, Türkmenlerin petrol bölgesinden sürülerek uluslararası güçlerin bölgedeki petrolü ele geçirmesi için uygulanan taktiklerin bir parçası olarak yorumlanmaktadır. Geleceğe yönelik konunun çözümüne ilişkin bir bakış açısı sağlamayı hedeflemeyen, bölgedeki çatışmanın farklı bir şekilde devam edeceğine dair yorumlarla süreci analiz etmektedir.

\section{Bulguların barış gazeteciliği açısından değerlendirilmesi}

Evrensel gazetesinin haberleri barış gazeteciliği açısından incelendiğinde; haberlerin şiddet/savaş yönlendirmeli olduğunu söylemek mümkündür. Çatışmanın biçimlenmesi açısından gazetenin konuyu; iki aktör üzerinden değerlendirdiği, ancak hedef ve mesele açısından konuyu bağlamı ve arka planı ile ele aldığı söylenebilir. Şiddetin etkileri süreğendir, IŞiD temsili üzerinden yürütülen savaş ise, barış ve özgürlük getireceği için "kutsaldır". Sorunun kaynağı savaştır, hatta savaşın arkasında yatan nedenlerdir. Sonucu ortaya çıkaran neden, aktöre indirgenmemiştir ve aktör, aslında bir ideoloji ve değerler siteminin temsilidir. Şiddet uygulayan IŞiD'dir ve çatışmanın diğer tarafı olan Ezidiler ve Kürtler, mağdur, bu mağduriyetten kurtulmak için meşru bir savaşa dâhil olan özneler olarak temsil edilmektedir. Barış, IşiD'in bölgeden silinmesi ile gelecektir çünkü IşiD, bölgenin ve bölge halklarının geleceği için tehdit oluşturmaktadır.

Birgün gazetesi barış gazeteciliği açısından incelendiğinde ise, çalışmaya konu olan haberlerin genel olarak şiddet/savaş yönlendirmeli olduğu söylenebilir. TiHV'nın raporunun haberleştirildiği 23 Ağustos tarihli haber istisna oluşturmak suretiyle tüm haberlerin metinleri IŞiD'e karşı Kürtleri sabitlemiş, Ezidileri ise mağdurlar olarak yerleştirmiştir. Özellikle Kürt silahlı güçlerinin IŞiD'e karşı birleşir gösterilmesi, Birgün gazetesinin çatışmayı biçimlendirirken "2 grup 1 hedef" şeklinde haber yapmasına imkân tanımıştır. Barış gazeteciliği bir savaşta ya da çatışmada pek çok grup ve pek çok hedef olduğunu ifşa etmek gerektiğin söylerken, Birgün gazetesinin söylemi, aksi şekilde şiddetin görünür etkileri üzerinde durmuş ve savaşı "cihatçı" IŞíD'e karşı kutsal bir anlatı içine yerleştirmiştir. İstisnasız her haberde sorunların kaynağı olarak IŞiD gösterilmiş, $A B D$ gibi figürler ise kimi zaman sorunun, kimi zaman çözümün tarafı olarak temsil edilmiştir.

Analize konu olan haberlerin hiçbirinde IŞiD'in sesi duyulmamaktadır. Bu yüzden de haberler propaganda formatında yapılmamıştır, öyle ki yaptığı katliamlar 
dışında sesi hiç duyulmayan IŞiD, bu sessizlik içerisinde ifşa edilecek yalanlar da söylememektedir. Öldürülen IŞiD militanları ancak resmi açıklamalardaki sayılar olarak kalmakta ve "cihatçı" IŞiD savaşın "kötü" tipini oynamaktadır. Barış gazeteciliğinin son kategorisi olarak da, barışın daim kılınmasına dair çabalar, yalnızca Birgün gazetesinin söylemine sığdıılamayacak gerekçelerle, haberlerde hiç yer bulmamıştır. Öyle ki barışı kurmanın yegâne yolu "cihatçı" ve dolayısıyla yayılmacı IŞiD örgütünün ortadan kaldırılmasından sonra müzakere edilecek bir husus gibi gözükmektedir.

Cumhuriyet gazetesinde çatışmanın tarafları net olarak belirtilmekte ve kullanılan kelimeler savaşı betimlemektedir. Çatışmanın çözümüne dair ipuçları vermekten ziyade, bölgenin durumuna ait tespitler yapılmıştır. Barış gazeteciliğinin önerdiği olası çözümler için yaratıcı zeminlere işaret etme misyonu bu haber pratiğinde gerçekleşememiştir. 17 Ağustos 2014 tarihli haberde geleceğe dair yapılan öngörüler yine savaşın nerede nasıl patlak verebileceğine yönelik olup, şu ifadeler dikkat çekmektedir: “... Ve burada ABD'nin hava desteği altında Peşmergenin kara harekâtının başlamasının eli kulağında olduğu söyleniyor."

Cumhuriyet gazetesi, dört hafta boyunca konuyu gündemde tutarak özellikle konunun insani kriz boyutuna dikkati çekmiştir. Çatışmanın çözümüne dair gerekli zeminin nasıl yaratılabileceğine dair görüşler yer almasa da, Birleşmiş Milletler yardımlarının bazı bölgelere ulaşmadığı yönünde verilen bilgiler, Ezidi ve Türkmenlerin sesinin uluslararası kamuoyuna duyurulması açısından önem taşımaktadır. Cumhuriyet'in kısmen de olsa barış gazeteciliği önermesine, ikiden fazla aktöre ses vermesi ve insani krizi önemsemesi bakımından yaklaştığı varsayılabilir. Ancak yine de, ötekileştiren bir hikâyeleştirme biçimi ve şeytanlaştırıcı söyleme teslim olunduğu gözlemlenmektedir.

Hürriyet gazetesinde, Ezidi halktan kişilerin özellikle kadın ve çocukların yaşadıklarına toplu olarak fotoğraflarda yer verildiği gibi, kişilerin kendi ağızlarından açıklamalara da yer verildiği görülmüştür. Bu durum barış gazeteciliğinin ilkelerinden olan resmi yetkililer dışında halkın sesine de yer vermeyi karşılamaktadır ancak Ezidi topluluğunun hâlihazırda yetkili resmi kurumlarının bulunmayışı da bu durumun nedeni olarak görülebilir. Hürriyet gazetesi haberleri, birçok açıdan barış gazeteciliği kriterlerine uygun görünmemektedir. Hiçbir haber tüm kriterleri karşılamadığı gibi, bütün haberlerde savaş haberciliği unsurları daha baskındır.

Sabah gazetesinde gerek haberlerin konumu ve azlı̆̆ı, gerekse de sadece kaç kişinin öldüğü ve yaralandığına dair nicel bilgilerin sunulması, gazetenin savaşa ve çatışmalara dair aktif bir rol ve sorumluluk üstlenmemeyi seçtiğini göstermektedir. Böyle bir sorumluluk üstlenmekten kaçınmakla birlikte, savaştan zarar gören tarafların kurbanlaştırıcı bir dille tanımlanmaları, ışiD'in önünde durabilecek hiçbir gücün bulunmadığı vurgusu veya silah ve mühimmat desteğinin artırılma çabasına yönelik haberler ise şiddeti beslediği için barış gazeteciliği için kabul edilebilir bir gazetecilik anlayışı değildir. 
Sabah gazetesi çoğunlukla, gerek şiddeti ayrıntılarıyla betimleyen tavrıyla, gerek metinler ve görseller aracıı̆̆ıyla kurduğu dille, gerekse de çatışmanın arka planına hiçbir şekilde değinmeden yalnızca "kimin" "ne" yaptığına dair sunduğu enformasyonla çatışmayı ve savaşı besleyen bir yaklaşım ortaya koymaktadır. Savaştan zarar görenlerin sesine zaman zaman yer verilmesi olumlu bir özellik olsa da, bu haberlerin hiçbiri gazetenin kendi çabasıyla okuyucuya ulaşması sonucu yapılmış haberler değil, başka kaynaklardan edindiği bilgilerle oluşturduğu haberlerdir. Üstelik haberlerin çoğunda elit odaklı tutuma, halk odaklı tutumdan daha fazla başvurulmuştur. Dolayısıyla gazetenin, barış gazeteciliği ilkelerini karşılamaktan uzak olduğunu söylemek mümkündür.

Yeniçağ gazetesi, kendilerini "Ezidi" olarak adlandıran bir etnik gruba, "Yezidiler" olarak hitap etmektedir. Yeniçağ bu tercihini tarihsel açıklamalara bağlayarak, bu kullanım şekillerini açıklamaya ve kabul ettirmeye çalışmıştır. Yeniçăg'ın, bu etnik grubu kendilerini ifade ettikleri gibi değil, kendi atfettikleri isimle anması, barış gazeteciliğinin ilkeleri ile uyuşmamaktadır. Yeniçağ haberlerinde Türkmenler dışında hiçbir tarafa söz verilmemiş, kısıtlı olarak Ezidilerin yaşadığı insani krize yer vermek dışında Ezidilere bu haberlerin tarafı olarak yer verilmemiştir. Türkmenler farklı etnik gruplarla karşılaştırılarak, diğer etnik gruba karşı mağdur olarak konumlandırımakta, tüm haberler Türkmenleri merkeze alarak sınırlı bir bakış açsından verilmektedir. Yeniçağ gazetesinin, Türkmenler dışında tüm etnik grupları ötekileştirici dili, barış gazeteciliğinin ulaşmak istediği amacın tam tersine hizmet etmektedir. Gazete, Sincar üzerinden, "Türklük ve Türk ırkına" ilişkin tarihsel ve güncel çatışmaları yeniden üreterek ve Türklük dışındaki tüm tarafları ötekileştirerek, konuyu tek boyutlu hale getirmektedir.

\section{Sonuç}

Çalışmanın bulguları değerlendirildiğinde, varsayımlarımızın büyük ölçüde doğrulandığı görülmüştür. Ezidi ve Türkmenlerin hedef alındığı saldırılar ve içinde bulundukları çatışmalara ilişkin haberler, gazetelerin siyasi tutumları ve dolayısıyla, siyasi iktidar karşısındaki konumlanışlarıyla paralellik göstermiştir. Benzer şekilde, Ezidiler ve Türkmenlerin temsili, gazetelere göre büyük ölçüde değişmiştir. Ezidilere dair haberlerin en çok yer aldığı Evrensel gazetesinde, yalnızca Türkmenlere ilişkin tek bir haber yapılmış; Türkmenler, IŞiD tarafından mağdur edilen ve buna karşı mücadele eden Ezidilerin ana aktör olduğu haberlerde ancak yan unsur olabilmişlerdir. Buna karşlık Türkmenlerin en çok temsil edildiği gazete Yeniçağ'da ise Ezidiler, "Yezidiler" olarak adlandırılmış ve ötekileştirilmişlerdir. Yapılan gazeteciliğin, "biz" ve "öteki" ikiliğini devam ettirdiği ve barış gazeteciliğinin imkânlarını boğduğunu söylemek mümkündür.

Haberlerin içerisindeki en temel unsurların aktarılması da dâhil olmak üzere söylemsel tercihler, gazetelerin yayın kimlikleri ve yayın politikaları ile ideolojik tutumlarına ilişkin önkabulleri desteklemiştir. IŞiD saldırısından etkilenen iki etnik grup olan Ezidilerin ve Türkmenlerin haberlerde yer alma ağırlığı da yine bu 
konumlanmalar ile doğrudan bağlantılıdır. En çok habere yer veren gazetelerin Evrense/ ve Yeniçağ olması; konunun diğer gazeteler için güncelliğini kaybettiği tarihlerde bile ardıl yönleriyle gazetelerin ana gündemleri arasında yer alması, tesadüf değildir. Bunun yanı sıra, Ezidiler ve Türkmenlerin, "mağdur" olan topluluklar olarak temsil edilmekten ziyade, ideolojik bir tutumla "biz/öteki" şeklinde temsil edildiği görülmüştür.

Elbette bu saptamalar, barış kaygısıyla yapılabilecek bir gazeteciliğin önündeki engellerle dolaysız bir biçimde bağlantılıdır. Örneğin yapısı gereği kâr amaçı bir özellik gösteren medyanın bu anlamda, tüm dünyada olduğu gibi Türkiye'de de barışı kısa vadede kârlı bulmaması hiç de şaşırılacak bir durum değildir. Shinar'ın (2004) da belirttiği gibi, rekabete, yüksek haber değerine ve izlenme oranlarına dayalı bir ekonomik yapılanmaya sahip medyanın, barış yerine savaşı tercih etmesi oldukça olağandır. Kurumsal engellerin yanı sıra kimi ideolojik yaklaşımlarda da barış gazeteciliğinin engelleri kapsamındadır. Araştırmamızın çoğu örneğinde de rahatlıkla gözlemlendiği üzere, medya uluslararası çatışmalar gibi konularda etnik merkezci bir dünya görüşüyle hareket etmekte veya kendini mevcut iktidarın politikalarından kolay kolay ayrı tutamamaktadır. Bu sebeple, örneğin Ezidilerin Evrensel gazetesi tarafından aşırı içselleştirici bir tonla sahiplenilmesi veya Yeniçağ'ın Ezidilerin yaşadıklarını neredeyse yok sayarak sadece Türkmenlerin sesine kulak vermesi ve onları sahiplenmesi, söz konusu ideolojik tutumlardan kaynaklanmaktadır.

İsgalin ardından yapılan tüm bu haberlerden yola çıkarak, Türkiye'de medyanın barışı özendirmede merkezi bir rol oynadığını, çatışma zamanlarında barışı özendirici bir misyonla hareket ettiğini söylemek ise ne yazık ki çok zor görünmektedir. Türkiye medyası, gerek söylemiyle, gerek olayın taraflarına dair tutumuyla, gerekse de görsellerin sunum biçimleriyle propaganda ve ajitasyon yoluna giderek, bir barış ortamı kurulmasına çalışmak şöyle dursun, şiddeti en detaylı hâliyle betimleyerek, bunun için nicel değerlere başvurmaktan da geri kalmadan, çözüm odaklı olmaktan son derece uzak bir gazetecilik anlayışı ortaya koymaktadır.

\section{Kaynakça}

Alankuş, S. (2016). Barış Gazeteciliği El Kitabı. İstanbul: IPS İletişim Vakfı.

Birgün gazetesi, 04-31 Ağustos 2014 sayıları.

Birleşmiş Milletler Insan Hakları Konseyi (5 Şubat 2013), Report of the Independent International Commission of Inquiry on the Syrian Arab Republic, Erişim: 03.01.2016. http://www.ohchr.org/Documents/HRBodies/HRCouncil/ ColSyria/A.HRC.22.59_en.pdf 
Birleşmiş Milletler İnsan Hakları Yüksek Komiserliği (Human Rıghts Office of the High Commissioner for Human Rights), Report on the Protection of Civilians in Armed Conflict in Iraq: 6 July - 10 September 2014, Erişim: 03.01.2016, http://www.ohchr.org/Documents/Countries/IQ/UNAMI_OHCHR_POC_Report_ FINAL_6July_10September2014.pdf

Cumhuriyet gazetesi, 04-31 Ağustos 2014 sayıları.

Doruk Ö. (2013). Disiplin Toplumu ve Haber Söylemi: Gökkuşağı Derneği'nce Yapılması Planlanan Yürüyüşün Engellemesine İlişkin Haberlerin Çözümlenmesi, Gümüşhane Üniversitesi İletişim Fakültesi Elektronik Dergisi. Mart 2013, Sayı 1, Cilt 2, Erişim: 05.01.2016, http://egifder.gumushane.edu.tr/article/ view/5000006384/5000006813

Durna, T. ve Kubilay, Ç. (2010). Söylem Kuramları ve Eleştirel Söylem Çözümlemeleri. Tezcan Durna (Der.), Medyadan Söylemler içinde (47-83). İstanbul: Libra.

Evrensel gazetesi, 04-31 Ağustos 2014 sayıları.

Giritli İnceoğlu, Y. ve Akgün Çomak, N. (2009). Teun A. Van Dijk. Y. G. İnceoğlu ve N.A. Çomak (Ed.), Metin Çözümlemeleri içinde (19-77). İstanbul: Ayrıntı.

Hürriyet gazetesi, 04-31 Ağustos 2014 sayıları.

Inal, M.A. (1996). Haberi Okumak. İstanbul: Temuçin.

Lynch, J ve McGoldrick, A. (2005) Peace Journalism: Conflict and Peacebuilding. Hawthorn Press.

McGoldrick, A. ve Lynch J. (2000). Peace Journalism: What is it? How to do it?. Erişim:11.12.2015. https://www.transcend.org/tri/downloads/McGoldrick_ Lynch_Peace-Journalism.pdf

Sabah gazetesi, 04-31 Ağustos 2014 sayıları.

Shinar, D. (2004). Media Peace Discourse: Constraints, Concepts and Building Blocks. Conflict \& Communication Online. Vol. 3, No. 1/2. Erişim: 05.01.2016, http://www.cco.regener-online.de/2004/pdf_2004/shinar_2004.pdf

Van Dijk, T.A. (1988). News Analysis: Case Studies of International and National News in the Pres. Hillsdale, NJ: Erlbaum.

Van Dijk, T.A. (1988). News as Discourse. Hillsdale, NJ: Erlbaum.

Van Dijk, T. (2015). Söylem ve İdeoloji: Çok Alanlı Bir Yaklaşım (N.Ateş, Çev.). B. Çoban ve Z. Özarslan, (Ed.), Söylem ve İdeoloji içinde (15-101). İstanbul: Su.

Yeniçağ gazetesi, 04-31 Ağustos 2014 sayıları.

31 Ekim 2016 - 06 Kasım 2016 haftası Tiraj Tablosu, Medyatava.com, Erişim: 14.11.2016, http://medyatava.com/tiraj 